\title{
Unlocking the Development of Hydropower Potential
}

Kamal Raj Dhungel

\begin{abstract}
Nepal is rich in hydropower amounted to $42 \mathrm{GW}$. But it is poor in terms of per capita electricity consumption amounted to $106 \mathrm{KWh}$ which keeps Nepal in a lowest position among the countries of South Asia. Harnessing this is a must for Nepal to run to the road to prosperity. Electricity use and economic growth move in the same direction indicating an additional unit of growth requires additional multiple unit of electricity. There are a number of stakeholders of the rivers flowing inside Nepal. These rivers are being shared by four sovereign countries -originated in Tibet, enter Nepal and cross the border to flow in India and then in Bangladesh before reaching their final destiny. These rivers provide drinking water to the people of these countries. In addition, another option for the benefit to share of these rivers among the stakeholders is to develop hydropower in Nepal and export it to light the cities of the rest of countries. Nepal should prepare itself to make favorable environment-creating domestic market, reducing electricity generation cost, maintaining rule of law, creating stable policies, ending political instability, adopting appropriate pricing policies- to invite foreign direct investment needed to harness.
\end{abstract}

Keywords: Development, Hydropower potential, Economy, Nepal

\section{Trade Transit Hub}

Tepal is one of the least developed countries in 1 the world. Geography has separated Nepal from all of the south Asian countries, except India linked neither through sea nor through land mass. However, Nepal is connected with China which of course makes it a key strategic country having an ideal prospective to integrate both the markets of China and India by facilitating and allowing trade and transit facilities. This type of integration will make Nepal a trade transit hub that encourages boosting tourism industry. The geography is not kind to undertake such venture showing a distant possibility to integrate markets of both of these countries through this way because of two obvious reasons. One, there is a direct link between both of these countries to open trade route up through their own borders. Two, the goods either manufactured in China or manufactured in India if traded in either of these countries through Nepal would incur high cost in comparison to direct trade operated through their own borders. Neither of these countries will chose former option in expense of later for the obvious reason that it enables to reduce transportation and dry port cost which makes goods cheaper to be traded in either markets of both of these countries.

\section{The Economy}

Nepal's economic size is small. It is one of the least developed countries of the world. A conflict prone distorted Nepal's economy depends heavily on the remittance and basic agriculture production. In addition, Nepal has been characterized by weak institutions and poor governance, a responsible factor among other to push Nepal into nearly a fail state. Lower size of per capita income amounted to 700 US dollar reveals the low level of development. Lower level of saving is the likely outcome of this situation. Low income means low saving. Low saving limits the size of the investment in an economy. The size of the investment in an economy depends on the size of saving. Low saving helps to allow vicious circle of low investment to continue. It limits the country's capacity to invest in the development projects.

The economic growth rate averaged around 3-4\% per annum. The growth rate primarily depends on the subsistence farming which in turn hinges on monsoon. Good monsoon yields good harvesting and vice versa. Good and bad harvesting depend on the good and bad monsoon. The growth rate fluctuates as the fluctuation in monsoon. The movement path of both real GDP and agriculture GDP seems same. It indicates that the main determinant of the growth rate of Nepalese economy is agriculture. Oscillatory behavior of annual growth of agriculture sector determines the more or less same behavior of the annual growth of real GDP. Among other things this could be the result of the uncertainty of monsoon.

\section{Sinful Water}

No easy solution for the utilization of water do exist. Water management itself is a sinful problem. Unknown factors with multiple dimensions to the science of the natural resources management make difficult to tackle. There are multiple stakeholders who hold an array of values inherent in water resources management, rendering decision making difficult (Smith and Porter, 2010). When talking to the immense water resources of Nepal, its utilization and management is more complex. All rivers are originated in Tibet, an autonomous region of China. They enter into Nepal and cross the Nepalese border to flow in India and then in Bangladesh before reaching to their final destiny. This indicates that rivers flowing in Nepal are being shared by four sovereign countries. These rivers are the source of drinking water, irrigation, flood control and electricity of the people of these sovereign countries. This adds more complexities to the utilization of water. However, Nepal is a country of few or limited alternatives to make choices as shown by self-proved evidences. Water resource is only the alternative on which Nepal's future prosperity depend. It is the free gift of nature. Geography gives Nepal a favorable terrain to 
become a hydro rich country. Hydropower is a clean and renewable energy. It has limited environmental impacts. Hydropower potential of Nepal if generated rationally could be the effective means for the fruits of these rivers to share among the stakeholders.

\section{Hydropower Potential}

Techno-economic feasible stock of hydropower is nearly 42 GW (Table 1). A few countries of the world have such opportunities. This opportunity to Nepal is gifted by nature itself. Its timely utilization in a rational manner would enable Nepalese to become prosperous. Modern age is the age of specialization. Most of the global economic activities are based on the comparative advantage to specialize. Nepal has few alternatives to chose to specialize. It has to depend on the development of hydropower. Nepal is facing with a contrast situation associated with the development of hydropower. Hydropower projects by nature are capital intensive. Huge investment is required to put them into action. Nepal has low capacity to invest in the economy while hydropower projects require high capacity. This situation calls for appropriate actions. If Nepal relies on the domestic capital to invest in the hydropower projects, it can barely generate electricity from small size plants to meet the growing domestic demand. It keeps Nepal in a stationary state (no change). No development, No progress. This is known as the state of inaction. This of course opens the door to break the ice to invite foreign investors to invest in the hydropower projects. A tiny proportion of this stock accounted nearly $1.5 \%$ so far is being harnessed.

\begin{tabular}{|l|l|l|l|}
\hline River Basin & Theoretical & Technical & Economical \\
\hline Sapta Koshi & 22 & 11 & 11 \\
\hline Gandaki & 21 & 6 & 5 \\
\hline Kainail \& Mahakali & 36 & 26 & 25 \\
\hline Southern Rivers & 4 & 1 & 1 \\
\hline Total & 83 & 44 & 42 \\
\hline
\end{tabular}

Table 1: Basin wise distribution of hydropower potential in GW

Source: Energy Synopsis Report, 1994

\section{Development Indicator}

Electricity is one of major sources of power for the nation's most economic activities to operate. Per capita electricity consumption is considered as one of the development indicator. Higher the per capita electricity consumption indicates the higher level of development. Nepal's installed electricity generation capacity (hydro and thermal) is $782.5 \mathrm{MW}$ (NEA, 2014). Nearly $50 \%$ of population has access to electricity with a very low per capita availability of $105.5 \mathrm{kWh}$. The per capita electricity consumption of Nepal is the lowest even among the South Asian countries Table 2. This indicates that Nepal's development is low among the south Asian nations judging from the perspective of per capita electricity consumption.

\section{Foreign Direct Investment}

Foreign Direct Investment (FDI) is a key to hydropower development. Multinational companies are searching lucrative areas to make their investment. The world is facing with a crisis of clean energy. Hydropower is a clean and renewable energy. Development of this industry to some extent can fill the vacuum of clean energy. In this context, global investors would pour a large amount of their money through FDI to harness hydropower potential of Nepal. Nepal is dependent on foreign investment for hydropower development. Both China and India have negotiated with the Nepalese Government to invest in large-scale hydropower projects. While this investment is positive for the Nepalese economy, China's and India's investment interests have wider geopolitical implications for the region. Economic development in both China and India requires more energy than either country can produce domestically. Competition over access to the Nepalese energy sector has the potential to create conflict between the two powers as they compete for regional hegemony. The inflow of FDI through third country investors is conditional. It is conditional upon the following.

\begin{tabular}{|c|c|c|}
\hline Country & $\begin{array}{l}\text { Electricity kwh } \\
\text { Consumption }\end{array}$ & $\begin{array}{l}\text { Rank out of 135 } \\
\text { countries }\end{array}$ \\
\hline Bangladesh & 259 & 118 \\
\hline Bhutan & 227 & 116 \\
\hline India & 684 & 107 \\
\hline Maldives & 605 & $124 / 118$ \\
\hline Nepal & 106 & 130 \\
\hline Pakistan & 49 & 115 \\
\hline Sri Lanka & 490 & 114 \\
\hline
\end{tabular}

Table 2: Per capita electricity consumption in 2011 (kWh/annum) Source: http:/www.nationmaster.com/index.php

\section{Good Governance}

The first condition is good governance. Good governance requires many things. Political stable nation could have good governance. Political instability neither is favorable to maintain good governance nor favorable to attract FDI. Commitment, devotion, responsibility, accountability and self-determination are needed. In the absence of these attributes, no country is successful to attract FDI. Politically stable countries such as China, Turkey, Malaysia, South Korea, even Nigeria, India, Brazil, South Africa are successful to attract FDI from the large international companies.

\section{Law and Order}

Maintaining the law and order situation is an essential part of attracting FDI. Weak law and order situation is a barrier for the FDI to come. A stable government having all the essentialities of good governance can provide a sense security to the foreign investment. Past history did not show any strong evidence that Nepal is committed to provide adequate security to the industries particularly operated through FDI. The basic infrastructure built in the project site of Upper Karnali was destroyed by locals. This helps to spread bad message to the community of international investors that Nepal is an insecure place to invest. Thus, Nepal has to place heavy efforts to improve law and order for giving a sense of security to the foreign investors. 


\section{Policy}

Stable and consistent policy is an essential part for FDI to come. Frequent changes in policy discourage investors to invest in hydropower sector. Income tax exemption, incentive and subsidies to be provided, profit to be deported, double tax avoidance, power purchase agreement, transmission line construction, addressing social and environmental issues, process and provision of licensing, etc should be provisioned clearly in the policy. If otherwise, unstable nature could distort the homogeneity. It could break the system. Politicians and decision makers can impose their own policy to serve their own interest differently to different investors. Such action discourages to genuine investors to come. Thus, Nepal needs to work to formulate policies favorable to investors.

\section{Market}

Investors seek reasonable profit from their investment. The profit is the deference between revenue and cost. Revenue can be generated through the sale of electricity. The size of the revenue depends primarily on the size of the market and scale of production. Market accessibility is the pre requisite for the new product to make happen. Desirable - volume of FDI requires adequate market to sale the new product to come. Nepal should have to search possible market at which the electricity is to be sold if it generates electricity from the large hydropower projects. Presently, Nepal has limited market accessibility if any it is constrained by adequate infrastructure.

\section{Income Sensitive}

The association between commercial energy consumption and economic development is direct and proportional (Hall et al.1986). However in a growing economy like Nepal, it is natural for the demand for commercial energy to grow faster than the income or any other indicator of economic development. An annual growth rate of $7-8 \%$ for the several years to come is required to make Nepal a prestigious and prosperous nation. For this to happen, Nepal should place efforts to carry out the development adventures. In particular anticipated economy growth depends primarily on the availability of energy to achieve. In Nepalese context, electricity consumption is highly associated with economic growth. Various studies reveals that a one unit economic growth requires more than three units of electricity to produce (Dhungel, 2009). It shows that the electricity consumption in Nepal is income sensitive. The reason for the high sensitivity of the demand for electric energy may be the preference of households and other production activities of electricity over other energy resources. As the income of the household sector increases they move from lower quality fuels to higher quality ones. Electricity is a cleaner, easier to use, efficient and environmentally benign source of energy. Other factors such as increasing urbanization, increasing industrial activities and people's increasing consciousness towards the social services (health and education may lead to an increase on the demand for electric energy. From this perspective, it is possible to predict the high income sensitivity of electricity of demand in Nepal (Dungel, 2003). The causality test suggests that the causality is running from per capita real GDP to per capita electricity consumption. It shows that it is the GDP that drives the electricity consumption and not vice versa. The implication is that energy conservation will not hurt economic growth and development, though it is sometimes argued that energy conservation may adversely affect economic growth. Hence, energy conservation can be a feasible policy tool for Nepal because the country is severely constrained by adequate investment needed for exploiting hydropower potential. Given that electricity supply in Nepal is insufficient to meet the growing demand as reflected by the frequent load shedding, a well designed conservation policy can play effective role in managing the energy supply sector (Dhungel,2008a, 2008b). The growth elasticity of foreign aid (FA) and GDP is 0.27 and 2.22 respectively. It indicates that the $1 \%$ change in foreign aid and GDP will change the electricity consumption by $0.27 \%$ and $2.27 \%$ respectively. The elasticity coefficient of FA is less than 1 indicating a less proportional change in electricity demand associated with the change in FA. However, the elasticity coefficient of GDP is greater than 1 indicating a more than proportional change in electricity demand associated with the change in GDP. It implies that change in electricity consumption is more sensitive associated with the change in GDP than the corresponding change in FA (Dhungel, 2014). It guides us to conclude that the demand for electrical energy highly sensitive to the changes in Gross Domestic Product (GDP). The average annual growth rate of electricity consumption has been found to exceed the growth rate of GDP, indicating that people or households have the intensity to climb up the highest ladder in spite of their income status. Thus Say's ${ }^{1}$ Law of Market, "Supply creates its own demand" is relevant to this particular product.

\section{Domestic Market}

Presently, above $90 \%$ of electricity has been consumed by residential sector. The demand is growing at an annual growth rate of 8-12\%. However, supply remains stagnant. Demand outstrips supply. The supply deficit is less than a thousand MW. It has resulted long hour power outage. A tiny volume ranges from 500 to 800 MW of electricity is being required to make Nepal a load shedding free economy. Evidently, it limits the domestic market. It is a discouraging factor for the FDI to come. No worrying matter! Scope is ahead. Nepal needs to gear up a greater speed to bring forth development adventures to enable the economy to grow at the faster rate that can help Nepal to become a comparable country with its neighbors. Both India and China are trying to take their economy to newer heights. Nepal has a challenging task to accomplish to carry its economy nearer to the economy of its neighbors. To be geared Nepal to the position of its neighbor it has to plan to achieve higher economic growth rate for several years to come. As discussed above, electricity demand is income sensitive. Higher growth in an economy to achieve requires multiple fold of the volume of electricity. Obviously, economic 
prosperity would create the market for the hydropower to be generated.

Among others, in order for electricity market to expand it must have a plan to build electric railway line in the east west highway, ropeway line to link one hill to another to facilitate goods and people to move and introduction of tram ways in metropolitan city like Kathmandu. It should continue to initiate to establish basic industries in the corridor of southern part. And finally, it should provide irrigation facility to modernize agriculture sector. Nepal is importing gas to meet the household demand to cook. Gas can be substituted by electricity. This will save hard currency that can be available for alternative uses. Reform in the domestic power market is a necessary condition for attracting foreign and domestic investment in the electricity industry for the reason that private power producers will seek greater power market. Industrial development is the prerequisite for the power market expansion and in turn it seeks reliable and adequate supply of electric energy.

\section{Hydropower for Export}

Water resources is natural gift to Nepal. Hydropower could be the reliable as well as renewable source of energy to supply not only in the national market but also in the huge markets of neighboring countries. As discussed, domestic market is limited for its full potential to consume. Obviously, hydropower if developed would seek foreign market. In this connection it would be appropriate to quote "The development of Nepal's hydropower sector is not a question of if, but, rather, when and by whom. A number of studies suggest that the total capacity of viable hydropower in the country is as much as 42,000 megawatts (MW). The maximum domestic demand, meanwhile, is projected at less than 7,000 MW in a high growth scenario over the next 25 years. This creates considerable potential for the export of hydro-energy ${ }^{2}$ ".Electricity trade is one of the possible ways to integrate the market of these countries in a meaningful way. Nepal and its neighbors particularly India should take advantage of this opportunity. The alignment of mutual interests and win-win opportunities for trade and cooperation should be particularly strong in the energy sector in general and hydropower sector in particular. Nepal is closely connected with the thickly populated areas of energy deficit (UP, Bihar, Uttaranchal, Haryana, Punjab, Delhi etc). Thus, Nepal should be in a position to supply electricity through energy trade to fill the gap by harnessing its hydropower potentiality for the benefit of India and derive significant gains for its own economy from energy imports and electricity export as it has been facing a long hour power outage. However, there are obstacles to conduct electricity trade to overcome. Almost complete absence of energy infrastructure linking the markets of these countries despite strong complementarities in hydroelectricity resource endowments.

\section{Cost of Generation}

Past evidences reveal that electricity generated through hydro incurred high cost. Per unit electricity cost in Nepal has exceeded the per unit electricity cost of India and China generated in an identical circumstances. This clearly proves that hydropower to be generated in Nepal would lose the competitive edge to export. Neighbors will not buy expensive electricity when the same is available in their own market at cheaper rate. In this connection Nepal should review the method it has adopted to generate electricity that regains competitive edge. Sound and modern technology could help to reduce unit cost of electricity generation. The technology transfer is being associated with FDI. FDI helps to bring better technology for reducing the unit cost of the electricity generation to apply. This would be the advantage of applying efficient technology to generate hydropower at lower cost.

\section{Pricing Strategy}

Tariff rate revision is a precondition for the increase in domestic electricity consumption. The prevailing exemption limit for residential electricity consumption does not permit to increase the demand for electricity. Reliability is another factor that sharply affects the consumption of electricity. With the increase in the reliability of the supply of electricity and sharp revision of the tariff rate with reasonable exemption limit, majority of the households in the urban area would be able to shift from the use of Liquefied Petroleum Gas (LPG) and kerosene to electricity consumption. However, consumer preferences would be guided by the comparative cost advantage. Therefore, decision makers and planners set their targets to increase the domestic consumption of electricity by way of setting price of the substitutable fuel. Market mechanism would be a better device for setting energy price than the administered one. However, there are various options to exploit water resource for which common commitment from the government and private sectors is needed. Small size of hydropower project ranging from a kW to a MW can be installed by mobilizing local resources particularly from the direct beneficiaries. Development and implementation of such projects will bring economic prosperity in the local level which can enhance human capability as a prerequisite for sustainable poverty reduction.

\section{Conclusion}

Anticipated economic growth needs smooth electricity supply. The average annual growth rate of electricity consumption has been found to exceed the growth rate of GDP, indicating that people or households have the tendency to climb up the highest ladder in spite of their income status. But since past two decades, power outage is being continued. It paralyses social and economic activities and hence in turn gives an adverse impact on economic growth. It indicates that Nepal is passing through a situation of undone. Poor governance breaks rule of law and stimulates corruption. Insecurity is rampant in every walk of life. Policies in place have largely been failed to attract FDI to come to harness hydropower potential. Market for 
electricity to sale, sound policies in place, strategies to apply competitive pricing policies and low cost generation strategies along with the infrastructural adequacy are the complementary parts of FDI to come. As water of rivers is shared by four sovereign countries, power sharing would be the best option to benefit accruing through developing hydropower potential of Himalayan region to all the countries. It helps for the built in regional market to ensure for power consumption and hence in turn would lay down the foundation for FDI to come.

Kamal Raj Dhungel is Professor at the Central Department of Economics in Tribhuvan University, Kathmandu, Nepal where he had received his Ph.D in 2008 on the topic "Trends and Patterns of Energy Consumption in Nepal". Prof. Dhungel has written more than a dozen academic books to name a few Readings in Nepalese Economy, A Hand Book of Cost Benefit Analysis, Energy Issues in Nepal: A Macro Level Analysis, and Investment Prospects and Challenges for Hydropower Development in Nepal. He has published more than ten dozen articles including in accredited journal articles. He has been involved in research activities since 1987 and has led several research teams. He is the editorial board member of the reputed international journalsPlatinum Global Journal of Social Science and Humanity (PGJSSH) and International Journal of Econometrics and Financial Management.

Corresponding address: kamal.raj.dhungel@gmail. com

\section{Foot Notes}

1. Supply side classical economist J B Say was being in favor of over production in an economy. $\mathrm{He}$ advocates that over production does not matter to happen because "Supply creates its own demand".

2. http://www.futuredirections.org.au/publications/ food-and-water-crises/2057-nepal-hydropowerand-geopolitics-balancing-interests-in-thetibetan-plateau.htmlNepal, Hydropower and Geopolitics: Balancing Interests in the Tibetan Plateau

\section{References}

Dhungel, K R (2014). On the Relationship between Electricity Consumption and Selected Macroeconomic Variables: Empirical Evidence from Nepal. Modern Economy, No. 5, California USA, PP.360-366.

Dhungel, K R (2009). Does Economic Growth in Nepal Cause Electricity Consumption, Hydro Nepal, Journal of Water Energy and Environment, Issue No. 5, pp. 47-51.

Dhungel, K R (2008a). A Causal Relationship between Energy Consumption and Economic Growth in Nepal, Asia Pacific Development Journal, 15(1) June 2008, UNSCAP, pp. 137-148.

Dhungel, K R (2008b). Regional Energy Trade in South Asia: Problems and Prospects, South Asia Economic Journal, 9(1) (2008), SAGE Publications, New Delhi, India, pp. 173-193

Dhungel, K R (2003). Income and Price Elasticity of the Demand for Energy: A Macro-level Empirical Analysis, Pacific and Asia Journal of Energy 13(2), New Delhi, India, pp.73-84.

Hall C A S, Cutler J C and Robert K (1986). Energy and Resource Quality: The Ecology of the Economic Process. NY, John Wiley \& Sons, Inc.

NEA, (2014). A Year in Review- Fiscal Year 2013/2014, Nepal Electricity Authority.

Smith, LED and Porter, KS (2010). Management of Catchments for the City Protection of Water Resources: Drawing on the New York City Watershed Experience. 